\title{
Disclosure Information
}

$\begin{array}{ll}\text { Abstract } & \text { Name } \\ 4 & \text { Marie Christine Aubry } \\ 44 & \text { Torsten O Nielsen } \\ 45 & \text { Vikram Deshpande } \\ 50 & \text { Torsten O Nielsen } \\ 64 & \text { Ahmet Dogan } \\ 71 & \text { Ravindra Kolhe } \\ 71 & \text { Alka Chaubey } \\ 71 & \text { Lisa C Watson } \\ 71 & \text { Claire Attwooll } \\ 113 & \text { Frederick L Baehner } \\ 113 & \text { Debbie McCullough } \\ 113 & \text { Carolyn Mies } \\ 113 & \text { Helen Bailey } \\ 146 & \text { Julia A Elvin } \\ 146 & \text { Kai Wang } \\ 146 & \text { Siraj M Ali } \\ 146 & \text { Jo-Anne Vergilio } \\ 146 & \text { Vincent A Miller } \\ 146 & \text { Philip J Stephens } \\ 146 & \text { Jeffrey S Ross } \\ 146 & \text { James Suh } \\ 148 & \text { Joel Lefferts } \\ 166 & \text { Shannon L Puhalla } \\ & \end{array}$

\section{Relevant Disclosure Information}

Consultant for Genentech; Honorarium.

Consultant for NanoString Technologies; Consulting fee. Partner of Bioclassifier LLC; Ownership. Speaker, research support for Affymetrix; Research support.

Consultant for NanoString Technologies; Consulting fee. Partner of Bioclassifier LLC; Ownership. Consultant for Foundation Medicine; Stipend. Advisory board for Cancer Genetics; Stipend.

Researcher for Affymetrix Inc.; Kits and Reagents (no direct financial benefit).

Speaker for Affymetrix; Travel benefits. Speaker for Cartagenia; Travel benefits.

Company Employee of Illumina, Inc; Salary and stocks.

Salaried Employee of Illumina, Inc; Salary.

Employee of Genomic Health, Inc.; Salary, stock.

Employee of Genomic Health Inc.; Salary, stock.

Employee of Genomic Health, Inc.; Salary.

Employee of Genomic Health, Inc.; Salary, stock.

Employee of Foundation Medicine, Inc.; Employment/equity interest.

Employee of Foundation Medicine, Inc.; Employment/equity interest.

Employee of Foundation Medicine, Inc.; Employment/equity interest.

Employee of Foundation Medicine, Inc.; Employment/equity interest.

Employee of Foundation Medicine, Inc.; Employment/equity interest.

Employee of Foundation Medicine, Inc.; Employment/equity interest.

Employee, research support for Foundation Medicine; Employment, equity.

Employee of Foundation Medicine, Inc.; Employment/equity interest.

Advisory board member for Roche Molecular Diagnostics; Consulting fee.

Local trial PI for Incyte; Research support. Local trial PI for Pfizer; Research support. Local trial PI for Lilly; Research support. Local trial PI for Novartis; Research support. Local trial PI, advisory committee for Abbvie; Research support. DSMB for Med Immune; Honorarium. DSMB for Celldex; Honorarium. Local trial PI for Covance Bayer; Research support.

Employment of Ventana Medical Systems, Inc.; Employment.

Employee, board member for G.P. has financial interest in Phi Optics, Inc., a company developing quantitative phase imaging technology for materials and life science applications; Salary, stocks.

Employee of Foundation Medicine, Inc.; Employment/equity interest.

Employee, research support for Foundation Medicine; Employment, equity.

Employee of Foundation Medicine, Inc.; Employment/equity interest.

Employee of Foundation Medicine, Inc.; Employment/equity interest.

Employee of Foundation Medicine, Inc.; Employment/equity interest.

Employee of Foundation Medicine, Inc.; Employment/equity interest.

Employee of Foundation Medicine, Inc.; Employment/equity interest.

Employee of Foundation Medicine, Inc.; Employment/equity interest.

Employee of Foundation Medicine, Inc.; Employment/equity interest.

Speaker and Consultant for ROCHE; Consultant fee.

Scientific advisory board member, scientific Consultant for Inspirata, Inc.; Equity holder. Scientific advisory board member, scientific Consultant for Elucid Bioimaging; Equity holder.

Employee of Foundation Medicine, Inc.; Employment/equity interest.

Employee of Foundation Medicine, Inc.; Employment/equity interest.

Employee of Foundation Medicine, Inc.; Employment/equity interest.

Employee of Foundation Medicine, Inc.; Employment/equity interest.

Employee of Foundation Medicine, Inc.; Employment/equity interest.

Employee of Foundation Medicine, Inc.; Employment/equity interest.

Employee of Foundation Medicine, Inc.; Employment/stock ownership.

Employee of Foundation Medicine, Inc.; Employment/equity interest.

Employee, research support for Foundation Medicine; Employment, equity.

Consultant for NanoString Technologies; Consulting fee. Partner of Bioclassifier LLC; Ownership. DSMB for Celldex; Honorarium. DSMB for Med Immune; Honorarium. Local trial PI, advisory committee for Abbvie; Research support. Local trial PI for Lilly; Research support. Local trial PI for Novartis; Research support. Local trial PI for Pfizer; Research support. Local trial PI for Incyte; Research support. Local trial PI for Covance Bayer; Research support.

Advisory board for Bristol Myers Squibb; Honorarium. Investigator-initiated Research for Bristol Myers Squibb; Research funding. Advisory board for Astra Zenica; Honorarium. 
Abstract Name

Leisha Emens
Michael Bonert

Liron Pantanowitz

Noa Davis

Claire M Eklund

Lynette M Sholl

A John Iafrate

Long Le

Elodie Sollier

Dino Di Carlo

Liron Pantanowitz

David Altree-Tacha

Krystal Brown

Richard J Wenstrup

M Bryan Warf

Kathryn A Kolquist

Jonathan Nelson

Rosalie Elenitsas

Jon A Reed

Darl D Flake

Loren E Clarke

Hillary Kimbrell

Benjamin B Roa

Barbara R DuPont

Ravindra Kolhe

Alka Chaubey

Jonhan Ho

Vincent A Miller

Jeffrey S Ross

Philip J Stephens

James Suh

Jo-Anne Vergilio

Julia A Elvin

Mark Bailey

Siraj M Ali

Aaron S Mansfield

Michael Bonert
Jeffrey S Ross

Derek B Allison

Minesh Lalla

Christopher J VandenBussche

Anil Parwani

\section{Relevant Disclosure Information}

Principal investigator-initiated study for Merck; Research funding. Principal investigator-initiated study for Genentech and Roche, Inc; Research funding. Principal investigator-initiated study for EMD Serono; Research funding. Principal investigator-initiated study for Astrazeneca; Research funding.

Employee, research support for Foundation Medicine; Employment, equity.

Research collaboration for Sienna Cancer Diagnostics Ltd.; Research materials.

Program development for R\&D for Sienna Cancer Diagnostics Ltd.; Employee of company.

Researcher for Sienna Cancer Diagnostics Ltd.; Salary support and research materials.

Dr. Parwani also formerly served as a consultant to Omnyx, LLC, through an agreement with the University of Pittsburgh Department of Pathology for Omnyx, LLC; Dr. Parwani was formerly employed by an affiliate of UPMC, which owns one half of Omnyx, LLC. He received research funding from Omnyx, LLC through the Univ. of Pitt, and has the right to receive proceeds from the sale of Omnyx or its products.

Consultant for Omnyx; Consulting fee.

Employee of Micromedic Technologies Ltd.; Salary.

Co-author of Hologic; Stock holdings in excess of $\$ 5000$.

Scientific advisory board for Genentech; Honorarium.

Preliminary patent application holder with the U.S. Patent Office for Anchored Multiplex-PCR technology for Archer Dx; Royalties and has equity in the company.

Preliminary patent application holder with the U.S. Patent Office for Anchored Multiplex-PCR technology for Archer Dx; Royalties and has equity in the company.

Chief scientific officer for Vortex Biosciences; Work for the company.

Consultant for Vortex Biosciences; Shares.

Consultant for Omnyx; Consulting fee.

Employee of Biocare Medical; Salary and minor stock holder.

Employee of Myriad Genetics, Inc.; Stock, salary.

Employee of Myriad Genetics, Inc.; Stock, salary.

Employee of Myriad Genetic Laboratories, Inc.; Stock, salary.

Employee of Myriad Genetic Laboratories, Inc.; Stock, salary.

Employee of Myriad Genetic Laboratories, Inc.; Stock, salary.

Textbook editor for Lippincott Williams Wilkins; Royalties.

Contracted Research for Myriad; Consulting fee. Employee/owner of CellNetix Pathology \& Labs; Salary.

Employee of Myriad Genetics, Inc.; Stock, salary.

Employee of Myriad Genetic Laboratories, Inc.; Stock, salary.

Employee of Myriad Genetic Laboratories, Inc.; Stock, salary.

Employee of Myriad Genetic Laboratories, Inc.; Stock, salary.

Speaker for Abbott; Travel funds.

Researcher for Affymetrix Inc.; Kits and Reagents (no direct financial benefit).

Speaker for Affymetrix; Travel benefits. Speaker for Cartagenia; Travel benefits.

Dr. Ho also serves as a consultant to Omnyx, LLC, through an agreement with the University of Pittsburgh Physicians Department of Dermatology for Omnyx, LLC; Jonhan Ho, MD is employed by an affiliate of UPMC, which owns one half of Omnyx, LLC. Dr. Ho has received research funding from Omnyx, LLC through the University of Pittsburgh, and has the right to receive proceeds from the sale of Omnyx or its products.

Employee of Foundation Medicine, Inc.; Employment/equity interest.

Employee, research support for Foundation Medicine; Employment, equity.

Employee of Foundation Medicine, Inc.; Employment/equity interest.

Employee of Foundation Medicine, Inc.; Employment/equity interest.

Employee of Foundation Medicine, Inc.; Employment/equity interest.

Employee of Foundation Medicine, Inc.; Employment/equity interest.

Employee of Foundation Medicine, Inc.; Salary/stock options.

Employee of Foundation Medicine, Inc.; Employment/equity interest.

Consulting for Celgene; Honorarium. Consulting for Genentech; Honorarium.

Founder / owner of Libre Pathology Limited; No financial benefit. Company runs librepathology. org - an open access creative commons licenced pathology wiki - without commercial sponsorship or advertisements.

Founder / owner of Libre Pathology Limited; No financial benefit. Company runs librepathology. org - an open access creative commons licenced pathology wiki - without commercial sponsorship or advertisements.

Histopatology consultation for Veracyte; Consulting fee. 


$\begin{array}{ll}\text { Abstract } & \text { Name } \\ 599 & \text { Erik K Alexander } \\ 609 & \text { Guido Rindi } \\ & \\ 611 & \text { Kyle Fedorchak } \\ 611 & \text { Jeffrey S Ross } \\ 611 & \text { Philip J Stephens } \\ 611 & \text { Vincent A Miller } \\ 611 & \text { Shakti H Ramkissoon } \\ 611 & \text { James Suh } \\ 611 & \text { Jo-Anne Vergilio } \\ 611 & \text { Siraj M Ali } \\ 611 & \text { Julia A Elvin } \\ 613 & \text { Erik K Alexander } \\ 621 & \text { Wade S Samowitz } \\ 626 & \text { Vikram Deshpande } \\ 627 & \text { Gregory Y Lauwers } \\ 628 & \text { Junko Aida } \\ 628 & \text { Kaiyo Takubo } \\ 629 & \text { Jeffrey S Ross } \\ 633 & \text { Gregory Y Lauwers } \\ 649 & \text { David L Rimm }\end{array}$

\section{Relevant Disclosure Information}

Consultant for Veracyte; Consulting fee.

Speaker for Novartis Pharma; Honorarium. Speaker for Ipsen Pharma; Honorarium. Consultant for Bracco Imaging; Honorarium.

Employee of Foundation Medicine, Inc.; Employment/equity interest.

Employee, research support for Foundation Medicine; Employment, equity.

Employee of Foundation Medicine, Inc.; Employment/equity interest.

Employee of Foundation Medicine, Inc.; Employment/equity interest.

Part-time pathologist for Foundation Medicine; Payment for work.

Employee of Foundation Medicine, Inc.; Employment/equity interest.

Employee of Foundation Medicine, Inc.; Employment/equity interest.

Employee of Foundation Medicine, Inc.; Employment/equity interest.

Employee of Foundation Medicine, Inc.; Employment/equity interest.

Consultant for Veracyte; Consulting fee.

Intellectual property licensed to Ventan for Ventana; Royalties for the BRAF V600E antibody.

Research support to institution for Affymetrix; Research support to institution.

Consultant for NinePoint; Consultation fee.

Diagnostic committee for Sucampo AG, Clinical trial SCMP-8811-201; Consigned research fund.

Diagnostic committee for Sucampo AG, Clinical trial SCMP-8811-201; Consigned research fund.

Employee, research support for Foundation Medicine; Employment, equity.

Consultant for NinePoint; Consultation fee.

Investigator, Consultant for Genoptix/Novartis; Support grant, honorarium. Consultant for ACD; Honorarium. Consultant for BMS; Honorarium. Consultant for Perkin-Elmer; Honorarium.

Consultant for Astra Zenica; Honorarium. Investigator for Cepheid; Support grant. Consultant for Amgen; Honorarium. Investigator for Gilead Sciences; Support grant. Consultant for Biocept; Honorarium. Consultant for Cernostics; Honorarium. Consultant for Metamark Genetics; Honorarium. Consultant for MDAgree; Honorarium. Consultant for OptraScan; Honorarium. Investigator for Kolltan; Support grant. Investigator for OncoplexDx; Support grant.

Advisory board for Celgene.

Research support to institution for Affymetrix; Research support to institution.

Consultant for NinePoint; Consultation fee.

Consultant for NinePoint; Consultation fee.

Employee of NinePoint Medical; Salary.

PI for Olympus Endoscopy; Research support for IRB approved studies. PI for Fuji-film; Research support for IRB approved studies. PI / Speaker for Cook Medical; Research support for IRB approved studies. PI / speaker / developer of training program for Boston Scientific; Research support for IRB approved studies. PI / speaker / developer of training program for GI solutions Covidien; Research support for IRB approved studies. PI for Erbe; Research support for IRB approved studies. PI for Ninepoint Medical; Research support for IRB approved studies. PI for C2 Therapeutics; Research support for IRB approved studies. PI for Cernostics; Research support for IRB approved studies. PI for Interpace; Research support for IRB approved studies.

Employee of NinePoint Medical; Salary.

Consultant for Boston Scientific; Honorarium. Consultant for Covidien; Honorarium.

Employee of Foundation Medicine, Inc.; Employment/equity interest.

Employee of Foundation Medicine, Inc.; Employment/equity interest.

Employee, research support for Foundation Medicine; Employment, equity.

Intellectual property licensed to Ventan for Ventana; Royalties for the BRAF V600E antibody.

Medical advisory committee for Diacarta; Travel support and shares.

Employee of Foundation Medicine, Inc.; Employment/stock ownership.

Employee of Foundation Medicine, Inc.; Employment/equity interest.

Employee, research support for Foundation Medicine; Employment, equity.

PI of clinical trial for Synta; Research support. PI on clinical trial for Novartis; Research support.

PI on clinical trial for Lily; Research support. PI on clinical trial for Roche/ Genenetech; Research support.

PI of clinical trial for Synta; Research support. PI on clinical trial for Novartis; Research support. PI on clinical trial for Lily; Research support. PI on clinical trial for Roche/ Genenetech; Research support.

Research support to institution for Affymetrix; Research support to institution.

Consultant for NinePoint; Consultation fee.

Research support to institution for Affymetrix; Research support to institution.

Consultant for NinePoint; Consultation fee.

Research support to institution for Affymetrix; Research support to institution. 


$\begin{array}{ll}\text { Abstract } & \text { Name } \\ 799 & \text { Shabana F Pasha } \\ 806 & \text { Robert Anders } \\ 806 & \text { Janis Taube } \\ 811 & \text { Jacques JGHM Bergman }\end{array}$

David T Ting

Vikram Deshpande

Alexander Miron

Kai Wang

Kyle Gowen

Siraj M Ali

Jeffrey S Ross

Vikram Deshpande

Jo-Anne Vergilio

Siraj M Ali

Julia A Elvin

James Suh

Vincent A Miller

Jeffrey S Ross

Philip J Stephens

Rohit Mehra

Charles Drake

Janis Taube

Michael J Bonham

John P Bennett

Phillip G Febbo

Athanasios C Tsiatis

Debbie McCullough

Ruixiao Lu

Francesc Xavier Bosch

Anthony M Magliocco

Eric A Klein

Jeffrey P Simko

\section{Emmanuel S Antonarakis}

Rajal Shah

Pradip Manna

Hongyang Pan

\section{Relevant Disclosure Information}

Consulting for Covidien; Honorarium. Speaker for Covidien; Honorarium. Research for Capsovision; Research support.

Research for BMS; Research funding.

Advisory board for Bristol Myers Squibb; Honorarium. Investigator-initiated Research for Bristol Myers Squibb; Research funding. Advisory board for Astra Zenica; Honorarium.

PI for Olympus Endoscopy; Research support for IRB approved studies. PI for Fuji-film; Research support for IRB approved studies. PI / Speaker for Cook Medical; Research support for IRB approved studies. PI / speaker / developer of training program for Boston Scientific; Research support for IRB approved studies. PI / speaker / developer of training program for GI solutions Covidien; Research support for IRB approved studies. PI for Erbe; Research support for IRB approved studies. PI for Ninepoint Medical; Research support for IRB approved studies. PI for C2 Therapeutics; Research support for IRB approved studies. PI for Cernostics; Research support for IRB approved studies. PI for Interpace; Research support for IRB approved studies.

Investigator for Celgene; Research funding. Investigator for Kinex; Research funding. Investigator for Astex Pharmaceuticals; Research funding. Investigator for Precision Biologics; Research funding. Investigator for Agios; Research funding. Investigator for Genentech; Research funding. Spoke at investigator meeting for Merck; Honoraria/ travel accommodations. Advisory role for DAVAOncology; Honoraria.

Research for Affymetrix; Research support.

Speaker, research support for Affymetrix; Research support.

CSO for Covariance Biosciences,LLC; Ownership interest.

Employee of Foundation Medicine, Inc.; Employment/equity interest.

Employee of Foundation Medicine, Inc.; Employment/stock ownership.

Employee of Foundation Medicine, Inc.; Employment/equity interest.

Employee, research support for Foundation Medicine; Employment, equity.

Research support to institution for Affymetrix; Research support to institution.

Employee of Foundation Medicine, Inc.; Employment/equity interest.

Employee of Foundation Medicine, Inc.; Employment/equity interest.

Employee of Foundation Medicine, Inc.; Employment/equity interest.

Employee of Foundation Medicine, Inc.; Employment/equity interest.

Employee of Foundation Medicine, Inc.; Employment/equity interest.

Employee, research support for Foundation Medicine; Employment, equity.

Employee of Foundation Medicine, Inc.; Employment/equity interest.

Patent for Gen-Probe, Inc.; Royalty.

Educational presentations and Consulting for Bristol-Myers-Squibb; Honorarium.

Advisory board for Bristol Myers Squibb; Honorarium. Investigator-initiated Research for Bristol Myers Squibb; Research funding. Advisory board for Astra Zenica; Honorarium.

Employee of Genomic Health, Inc.; Salary, stock.

Employee of Genomic Health, Inc.; Salary, stock.

Employee of Genomic Health, Inc.; Salary, stock.

Employee of Genomic Health, Inc.; Salary, stock.

Employee of Genomic Health Inc.; Salary, stock.

Employee of Genomic Health, Inc.; Salary, stock.

Speaker for gsk; Research grants / conference. Speaker for Merck; Research grants / conference.

Advisor for qiagen; Conference.

Medical advisory committee for Diacarta; Travel support and shares.

Speaker for Genomic Health, Inc.; Speaker fee.

Consultant for Genomic Health, Inc.; Fees paid to my employer, UCSF. Research project collaborator for Genomic Health Inc.; Unrestricted research funds paid to my employer. Research project collaborator for Myriad Genetics; Unrestricted research funds paid to my employer. Consultant for GenomeDx; Fees paid to my employer, UCSF. Research project collaborator for Genome Dx; Unrestricted research funds paid to my employer. Manuscript writing for Maximum medical solutions; Honorarium to my employer, UCSF. Meeting attendee for Prostate Cancer Foundation; Travel reimbursement. Meeting attendee for Canary Foundation; Travel reimbursement. Scientific advisory board for 3D biopsy Inc; Honorarium.

Paid consultant/advisor for Sanofi US; Paid consultant/advisor. Paid consultant/advisor for Dendreon; Paid consultant/advisor. Paid consultant/advisor for Janssen Biotech; Paid consultant/ advisor.

Employee of Miraca Life Sciences; Salary.

Employee of Physicians Reference Lab, LLC; Salary.

Employee of Epitomics, an Abcam company; Employee salary. 


$\begin{array}{ll}\text { Abstract } & \text { Name } \\ 976 & \text { Jason Law } \\ 976 & \text { Jackie Chan } \\ 976 & \text { Yuekai Zhang } \\ 976 & \text { Taiying Chen } \\ 976 & \text { Aihua Li } \\ 977 & \text { Rajal Shah } \\ 977 & \text { Savvas Mendrinos } \\ 977 & \text { Wei Tian } \\ 978 & \text { Rajal Shah } \\ 979 & \text { Wei Tian } \\ 979 & \text { Rajal Shah } \\ 979 & \text { Savvas Mendrinos } \\ 984 & \text { Emmanuel S Antonarakis }\end{array}$

Todd Morgan

Arul M Chinnaiyan Scott A Tomlins

\section{Rohit Mehra} Dejan Knezevic Michael J Bonham Athanasios C Tsiatis Tara Maddala Anne Dee H Jeffrey Lawrence Phillip G Febbo Eric A Klein Anil Parwani

\section{Andrew Evans}

$$
\text { Jeffrey S Ross }
$$

Julia A Elvin

Siraj M Ali

Jo-Anne Vergilio

James Suh

Vincent A Miller

Philip J Stephens

Bruce Neri

Bryan Wittman

Andrew Evans

\section{James Bentley}

\section{Monica Chaterjee}

Gloria Romerocases

Wei Tian

Yousef Tadros

Jiyoon Yoon

Savvas Mendrinos

Rajal Shah

Wei Tian

Rajal Shah

\section{Relevant Disclosure Information}

Employee of Abcam; Salary.

Employee of Abcam; Salary.

Employee of Epitomics, an Abcam company; Employee salary.

Employee of Abcam; Salary and stock options.

Employee of Abcam; Salary.

Employee of Miraca Life Sciences; Salary.

Employee of Miraca Life Sciences; Salary.

Employee of Miraca Life Sciences; Salary.

Employee of Miraca Life Sciences; Salary.

Employee of Miraca Life Sciences; Salary.

Employee of Miraca Life Sciences; Salary.

Employee of Miraca Life Sciences; Salary.

Paid consultant/advisor for Sanofi US; Paid consultant/advisor. Paid consultant/advisor for Dendreon; Paid consultant/advisor. Paid consultant/advisor for Janssen Biotech; Paid consultant/ advisor.

Advisory board for MDxHealth; Honorarium. Advisory board for Genomic Health; Honorarium. Advisory board for Myriad Genetics; Honorarium.

Patent for Gen-Probe, Inc.; Royalty.

Consultant for Ventana Medical Systems and Abbvie; Honorarium. Licensced intellectual property for Ventana Medical Systems; Patent royalties. Licensced intellectual property for GenProbe/Hologic; Patent royalties. Sponsored research agreement for Compendia Bioscience/Life Technologies/ThermoFisher Scientififc; Research funding.

Patent for Gen-Probe, Inc.; Royalty.

Employee of Genomic Health, Inc.; Salary, stock.

Employee of Genomic Health, Inc.; Salary, stock.

Employee of Genomic Health, Inc.; Salary, stock.

Employee of Genomic Health, Inc.; Salary, stock.

Employee of Genomic Health, Inc.; Salary, stock.

Employee of Genomic Health, Inc.; Salary, stock.

Employee of Genomic Health, Inc.; Salary, stock.

Speaker for Genomic Health, Inc.; Speaker fee.

Dr. Parwani also formerly served as a consultant to Omnyx, LLC, through an agreement with the University of Pittsburgh Department of Pathology for Omnyx, LLC; Dr. Parwani was formerly employed by an affiliate of UPMC, which owns one half of Omnyx, LLC. He received research funding from Omnyx, LLC through the Univ. of Pitt, and has the right to receive proceeds from the sale of Omnyx or its products.

Consultant's role on clinical trial design and product improvement/development for Omnyx, LLC; Consultant fees.

Employee, research support for Foundation Medicine; Employment, equity.

Employee of Foundation Medicine, Inc.; Employment/equity interest.

Employee of Foundation Medicine, Inc.; Employment/equity interest.

Employee of Foundation Medicine, Inc.; Employment/equity interest.

Employee of Foundation Medicine, Inc.; Employment/equity interest.

Employee of Foundation Medicine, Inc.; Employment/equity interest.

Employee of Foundation Medicine, Inc.; Employment/equity interest.

Employee of Metabolon Inc; Salary.

Employee of Metabolon Inc; Salary.

Consultant's role on clinical trial design and product improvement/development for Omnyx, LLC;

Consultant fees.

Employee of Miraca Life Sciences; Salary.

Employee of Miraca Life Sciences; Salary.

Employee of Miraca Life Sciences; Salary.

Employee of Miraca Life Sciences; Salary.

Employee of Miraca Life Sciences; Salary.

Employee of Miraca Life Sciences; Salary.

Employee of Miraca Life Sciences; Salary.

Employee of Miraca Life Sciences; Salary.

Employee of Miraca Life Sciences; Salary.

Employee of Miraca Life Sciences; Salary. 


\section{Abstract Name}

1045

Scott A Tomlins

1048

1049

1053

1053

1058

1058

1058

1058

1065

1065

1066

1066

1082

1092

1092

1092

1092

1092

1096

1109

1123

1123

1123

1123

1123

1123

1123

1123

1123

1123

1123

1123

1135

1144

1144

1144

1144

1158

1170

1170
Rohit Mehra

David Tacha

Janis Taube

Charles Drake

Wendy L Flejter

Rajal Shah

Eric Kroman

Wei Tian

Rohit Mehra

Arul M Chinnaiyan

Arul M Chinnaiyan

Rohit Mehra

Jeffrey S Ross

Robert Makowsky

Chris Roberts

Miriana Moran

Craig Stephens

Stephanie H Astrow

Drucilla Roberts

David L Rimm

Philip J Stephens

Jeffrey S Ross

Vincent A Miller

Siraj M Ali

Laurie Gay

Jo-Anne Vergilio

Garrett Frampton

Julia A Elvin

Zachary Chalmers

Eric M Sanford

James Sun

James Suh

Vikram Deshpande

F Stephen Hodi

Margaret A Shipp

Gordon J Freeman

Scott Rodig

Mark H Stoler

Josh Haimes

Namitha Manoj

\section{Relevant Disclosure Information}

Consultant for Ventana Medical Systems and Abbvie; Honorarium. Licensced intellectual property for Ventana Medical Systems; Patent royalties. Licensced intellectual property for GenProbe/Hologic; Patent royalties. Sponsored research agreement for Compendia Bioscience/Life Technologies/ThermoFisher Scientififc; Research funding.

Patent for Gen-Probe, Inc.; Royalty.

Employee of Biocare Medical; Stock.

Advisory board for Bristol Myers Squibb; Honorarium. Investigator-initiated Research for Bristol Myers Squibb; Research funding. Advisory board for Astra Zenica; Honorarium.

Educational presentations and Consulting for Bristol-Myers-Squibb; Honorarium.

Employee of Miraca Life Sciences; Salary.

Employee of Miraca Life Sciences; Salary.

Employee of Miraca Life Sciences; Salary.

Employee of Miraca Life Sciences; Salary.

Patent for Gen-Probe, Inc.; Royalty.

Patent for Gen-Probe, Inc.; Royalty.

Patent for Gen-Probe, Inc.; Royalty.

Patent for Gen-Probe, Inc.; Royalty.

Employee, research support for Foundation Medicine; Employment, equity.

Research work for Response Genetics, Inc; Regents and instrument. Research work for HTG

Molecular Genetics, Inc; miRNA sequencing.

Research work for Response Genetics, Inc; Reagents and instrument. Research work for HTG

Molecular Genetics, Inc; miRNA sequencing.

Research work for Response Genetics, Inc; Reagents and instrument. Research work for HTG

Molecular Genetics, Inc; miRNA sequencing.

Research work for Response Genetics, Inc; Reagents and instrument. Research work for HTG

Molecular Genetics, Inc; miRNA sequencing.

Research work for Response Genetics, Inc; Reagents and instrument. Research work for HTG

Molecular Genetics, Inc; miRNA sequencing.

Author of UpToDate; Royalties.

Investigator, Consultant for Genoptix/Novartis; Support grant, honorarium. Consultant for ACD;

Honorarium. Consultant for BMS; Honorarium. Consultant for Perkin-Elmer; Honorarium.

Consultant for Astra Zenica; Honorarium. Investigator for Cepheid; Support grant. Consultant for

Amgen; Honorarium. Investigator for Gilead Sciences; Support grant. Consultant for Biocept;

Honorarium. Consultant for Cernostics; Honorarium. Consultant for Metamark Genetics;

Honorarium. Consultant for MDAgree; Honorarium. Consultant for OptraScan; Honorarium.

Investigator for Kolltan; Support grant. Investigator for OncoplexDx; Support grant.

Employee of Foundation Medicine, Inc.; Employment/equity interest.

Employee, research support for Foundation Medicine; Employment, equity.

Employee of Foundation Medicine, Inc.; Employment/equity interest.

Employee of Foundation Medicine, Inc.; Employment/equity interest.

Employee of Foundation Medicine, Inc.; Salary/stock options.

Employee of Foundation Medicine, Inc.; Employment/equity interest.

Employee of Foundation Medicine, Inc.; Employment/equity interest.

Employee of Foundation Medicine, Inc.; Employment/equity interest.

Employee of Foundation Medicine, Inc.; Employment/equity interest.

Employee of Foundation Medicine, Inc; Compensation and equity interest.

Employee of Foundation Medicine, Inc.; Employment/stock ownership.

Employee of Foundation Medicine, Inc.; Employment/equity interest.

Research support to institution for Affymetrix; Research support to institution.

Consultant/clinical Research support to institution for Bristol-Myers Squibb; Non-Paid.

Consultant/clinical Research support to institution for Genentech; Non-Paid. Consultant for Merck;

Honorarium. Consultant for Merck; Honorarium.

for Bristol-Myers-Squibb; Research funding.

Patent application for the use of 9A11 antibody for diagnostic purposes for Bristol-Myers-Squibb, Roche, Merck, EMD-Serrono, Boehringer-Ingelheim, Amplimmune/AstraZeneca, and Novartis;

Patent royalties on the PD-1 pathway.

for Patent application for the use of the 9A11 antibody for diagnostic purposes; None. for Bristol-

Myers-Squibb; Research funding.

Consultant for Advanced Cell Diagnostics; HPV ISH reagents.

Employee of ArcherDX, Inc; Salary.

Employee of ArcherDX, Inc; Salary. 


\section{Abstract Name}

1170

1174

1174

1174

1174

1181

1182

1221

1221

1227

1234

1240

1260

1260

1260

1260

1260

1260

1260

1260

1260

1267

1278

1284

1287

1287

1287

1287

1287

1287

1287

1287

1306

1331

1336

1340
Vikram Deshpande Tracy I George

Brian Kudlow Julia A Elvin

Joel Greenbowe

Jeffrey S Ross

Siraj M Ali

Mark H Stoler

Mark H Stoler

Jacob P Crowley

Anthony M Magliocco

Vikram Deshpande

Frank Campbell

Anthony M Magliocco

Julia A Elvin

Jeffrey S Ross

Philip J Stephens

Vincent A Miller

Jo-Anne Vergilio

Kyle Gowan

Kyle Fedorchak

Siraj M Ali

James Suh

Janis Taube

Scott A Tomlins

Andrew G Sikora

Vincent A Miller

Jeffrey S Ross

Philip J Stephens

Jo-Anne Vergilio

Julia A Elvin

Siraj M Ali

Kyle Fedorchak

James Suh

Vikram Deshpande

Tracy I George

Robert S Ohgami

David Tacha

Scott Rodig

Tracy I George

Ahmet Dogan

Gordon J Freeman

\section{Relevant Disclosure Information}

Employee of ArcherDX, Inc; Salary.

Employee of Foundation Medicine, Inc.; Employment/equity interest.

Employee of Foundation Medicine; Employee, equity.

Employee, research support for Foundation Medicine; Employment, equity.

Employee of Foundation Medicine, Inc.; Employment/equity interest.

Consultant for Advanced Cell Diagnostics; HPV ISH reagents.

Consultant for Advanced Cell Diagnostics; HPV ISH reagents.

Field application scientist for Affymetrix Inc.; Salary.

Medical advisory committee for Diacarta; Travel support and shares.

Research support to institution for Affymetrix; Research support to institution.

Senior scientist for Covariance Biosciences, LLC; Salary.

Medical advisory committee for Diacarta; Travel support and shares.

Employee of Foundation Medicine, Inc.; Employment/equity interest.

Employee, research support for Foundation Medicine; Employment, equity.

Employee of Foundation Medicine, Inc.; Employment/equity interest.

Employee of Foundation Medicine, Inc.; Employment/equity interest.

Employee of Foundation Medicine, Inc.; Employment/equity interest.

Employee of Foundation Medicine, Inc.; Employment/equity interest.

Employee of Foundation Medicine, Inc.; Employment/equity interest.

Employee of Foundation Medicine, Inc.; Employment/equity interest.

Employee of Foundation Medicine, Inc.; Employment/equity interest.

Advisory board for Bristol Myers Squibb; Honorarium. Investigator-initiated Research for Bristol

Myers Squibb; Research funding. Advisory board for Astra Zenica; Honorarium.

Consultant for Ventana Medical Systems and Abbvie; Honorarium. Licensced intellectual

property for Ventana Medical Systems; Patent royalties. Licensced intellectual property for Gen-

Probe/Hologic; Patent royalties. Sponsored research agreement for Compendia Bioscience/Life

Technologies/ThermoFisher Scientififc; Research funding.

PI for Advaxis; Funding of clinical trial.

Employee of Foundation Medicine, Inc.; Employment/equity interest.

Employee, research support for Foundation Medicine; Employment, equity.

Employee of Foundation Medicine, Inc.; Employment/equity interest.

Employee of Foundation Medicine, Inc.; Employment/equity interest.

Employee of Foundation Medicine, Inc.; Employment/equity interest.

Employee of Foundation Medicine, Inc.; Employment/equity interest.

Employee of Foundation Medicine, Inc.; Employment/equity interest.

Employee of Foundation Medicine, Inc.; Employment/equity interest.

Speaker, research support for Affymetrix; Research support.

PI for Allakos, Inc.; Research funding for mast cell research. Steering committee for clinical trial, mastocytosis for Novartis, Inc.; Consulting fees. Consultant to plan clinical trial, mastocytosis for Blueprint Medicine; Consulting fees. AML/MDS database steering committee for Celgene; Consulting fees.

Research support to institution for Affymetrix; Research support to institution.

PI for Allakos, Inc.; Research funding for mast cell research. Steering committee for clinical trial, mastocytosis for Novartis, Inc.; Consulting fees. Consultant to plan clinical trial, mastocytosis

for Blueprint Medicine; Consulting fees. AML/MDS database steering committee for Celgene;

Consulting fees.

Primary Investigator for Agilent Technologies; Research grant. Primary Investigator for

Foundation Medicine; Research support.

Employee of Biocare Medical; Stock.

for Patent application for the use of the 9A11 antibody for diagnostic purposes; None. for BristolMyers-Squibb; Research funding.

PI for Allakos, Inc.; Research funding for mast cell research. Steering committee for clinical trial, mastocytosis for Novartis, Inc.; Consulting fees. Consultant to plan clinical trial, mastocytosis

for Blueprint Medicine; Consulting fees. AML/MDS database steering committee for Celgene;

Consulting fees.

Consultant for Foundation Medicine; Stipend. Advisory board for Cancer Genetics; Stipend.

Patent application for the use of 9A11 antibody for diagnostic purposes for Bristol-Myers-Squibb, Roche, Merck, EMD-Serrono, Boehringer-Ingelheim, Amplimmune/AstraZeneca, and Novartis;

Patent royalties on the PD-1 pathway. 


\begin{tabular}{|c|c|}
\hline Abstract & Name \\
\hline 1379 & F Stephen Hodi \\
\hline $\begin{array}{l}1379 \\
1379\end{array}$ & $\begin{array}{l}\text { Margaret A Shipp } \\
\text { Scott Rodig }\end{array}$ \\
\hline $\begin{array}{l}1382 \\
1387 \\
1387 \\
1392\end{array}$ & $\begin{array}{l}\text { Ahmet Dogan } \\
\text { Vikram Deshpande } \\
\text { Robert P Hasserjian } \\
\text { Robert S Ohgami }\end{array}$ \\
\hline 1393 & Anna Porwit \\
\hline $\begin{array}{l}1408 \\
1408 \\
1409 \\
1409 \\
1409 \\
1409 \\
1412\end{array}$ & $\begin{array}{l}\text { David W Scott } \\
\text { Randy D Gascoyne } \\
\text { Ravindra Kolhe } \\
\text { Alka Chaubey } \\
\text { Lisa C Watson } \\
\text { Claire Attwooll } \\
\text { Robert S Ohgami }\end{array}$ \\
\hline $\begin{array}{l}1427 \\
1432\end{array}$ & $\begin{array}{l}\text { Robert P Hasserjian } \\
\text { Tracy I George }\end{array}$ \\
\hline
\end{tabular}

1440

1448

1462

1462

1470

1473

1473

1474

1475

1475

1481

1505

1505

1505

1505

1505

1505

1505

1505

1505

1505

1506

\author{
Dennis O’Malley \\ Ahmet Dogan \\ Robert P Hasserjian \\ Olga Pozdnyakova \\ Jeffrey S Ross \\ Tracy I George
}

Robert P Hasserjian
Ahmet Dogan
Ahmet Dogan
Ross Levine
Ahmet Dogan
Jie He
Jeffrey S Ross
Vincent A Miller
Rachel Erlich
James Suh
Julia A Elvin
Justin Allen
Samantha Morley
Jo-Anne Vergilio
Philip J Stephens
Tracy I George

Robert P Hasserjian Tracy I George 


$\begin{array}{ll}\text { Abstract } & \text { Name } \\ 1516 & \text { Robert P Hasserjian } \\ 1517 & \text { Dennis O'Malley } \\ 1518 & \text { Dennis O’Malley } \\ 1542 & \text { Yuling Luo } \\ 1542 & \text { Xiao-Jun Ma } \\ 1543 & \text { Douglas J Hartman } \\ 1549 & \text { Michelle Call } \\ 1549 & \text { Sushama Thakker } \\ 1549 & \text { Charlie Kim } \\ 1549 & \text { Glenda Anderson } \\ 1555 & \text { Jeffrey L Fine } \\ 1557 & \text { Jeffrey L Fine } \\ 1557 & \text { Liron Pantanowitz } \\ 1557 & \text { Curtis Stratman } \\ 1557 & \text { Douglas J Hartman } \\ 1557 & \text { Joe Birsa } \\ 1557 & \text { Jonhan Ho }\end{array}$

1557

1560

1560

1561

1561

1562

1563

Dhaval H Palsana

Katy Wack Laura M Drogowski Jonhan Ho

\section{Relevant Disclosure Information}

Consultant for Incyte, Inc.; Salary. Employee of Clarient Pathology Services; Salary. Employee of Clarient Pathology Services; Salary. Employee of Advanced Cell Diagnostics; Stock.

Employee of Advanced Cell Diagnostics; Employee.

Consultant for Omnyx; Consulting fee.

Employee of Farsight Genome Systems; Employee compensation.

Employee of Farsight Genome Systems; Employee compensation.

Employee of Farsight Genome Systems; Employee compensation.

Employee of Farsight Genome Systems; Employee compensation.

Inventor of Omnyx; IP agreement.

Inventor of Omnyx; IP agreement.

Consultant for Omnyx; Consulting fee.

Employee of Omnyx, LLC; Salary.

Consultant for Omnyx; Consulting fee.

Employee of Omnyx; Salary.

Dr. Ho also serves as a consultant to Omnyx, LLC, through an agreement with the University of Pittsburgh Physicians Department of Dermatology for Omnyx, LLC; Jonhan Ho, MD is employed by an affiliate of UPMC, which owns one half of Omnyx, LLC. Dr. Ho has received research funding from Omnyx, LLC through the University of Pittsburgh, and has the right to receive proceeds from the sale of Omnyx or its products.

Employee of Omnyx, LLC; Salary.

Consultant for Omnyx; Consulting fee.

Consultant for Omnyx; Consulting fee.

Employee of Inspirata, Inc; Equity holder, salary.

Scientific advisory board member, scientific Consultant for Inspirata, Inc.; Equity holder. Scientific advisory board member, scientific Consultant for Elucid Bioimaging; Equity holder.

Scientific advisory board member, scientific Consultant for Inspirata, Inc.; Equity holder. Scientific advisory board member, scientific Consultant for Elucid Bioimaging; Equity holder.

Was responsible for digital imaging of the glass slides using the mWSI technique I invented (played no part in the design of this study) for CEO, Co-founder and major share holder in AlexaPath (start-up focused on developing low cost medical diagnostic tools); No financial gain related to this project.

Was responsible for digital imaging of the glass slides using the mWSI technique I invented (played no part in the design of this study) for CTO, co-founder and major share holder in AlexaPath (start-up focused on developing low cost medical diagnostic ols); No financial gain related to this project.

Scientific advisory board member, scientific Consultant for Inspirata, Inc.; Equity holder. Scientific advisory board member, scientific Consultant for Elucid Bioimaging; Equity holder.

Consultant for Omnyx; Consulting fee.

Inventor of Omnyx; IP agreement.

Consultant for Omnyx; Consulting fee.

Work done in the study for Omnyx, LLC; Hourly for professional services rendered.

Senior VP of clinical and medical affairs at Omnyx, LLC for Omnyx, LLC; Salary.

Dr. Parwani also formerly served as a consultant to Omnyx, LLC, through an agreement with the University of Pittsburgh Department of Pathology for Omnyx, LLC; Dr. Parwani was formerly employed by an affiliate of UPMC, which owns one half of Omnyx, LLC. He received research funding from Omnyx, LLC through the Univ. of Pitt, and has the right to receive proceeds from the sale of Omnyx or its products.

Lead clinical scientist at Omnyx, LLC for Omnyx, LLC; Salary.

Research Manager at Omnyx, LLC for Omnyx, LLC; Salary.

Dr. Ho also serves as a consultant to Omnyx, LLC, through an agreement with the University of Pittsburgh Physicians Department of Dermatology for Omnyx, LLC; Jonhan Ho, MD is employed by an affiliate of UPMC, which owns one half of Omnyx, LLC. Dr. Ho has received research funding from Omnyx, LLC through the University of Pittsburgh, and has the right to receive proceeds from the sale of Omnyx or its products.

Consultant's role on clinical trial design and product improvement/development for Omnyx, LLC; Consultant fees.

Scientific advisory board member, scientific Consultant for Inspirata, Inc.; Equity holder. Scientific advisory board member, scientific Consultant for Elucid Bioimaging; Equity holder.

Consultant for Incyte; Honorarium. Consultant for Promedior; Honorarium. 


$\begin{array}{ll}\text { Abstract } & \text { Name } \\ 1584 & \text { Robert P Hasserjian } \\ 1630 & \text { Vikram Deshpande } \\ 1653 & \text { Vikram Deshpande } \\ 1685 & \text { Benjamin R Kipp } \\ 1696 & \text { Shakti H Ramkissoon } \\ 1699 & \text { Garrett Frampton } \\ 1699 & \text { Jeffrey S Ross } \\ 1699 & \text { Philip J Stephens } \\ 1699 & \text { Vincent A Miller } \\ 1699 & \text { Julia A Elvin } \\ 1699 & \text { Shakti H Ramkissoon } \\ 1699 & \text { Jo-Anne Vergilio } \\ 1699 & \text { Juliann Chmielecki } \\ 1699 & \text { Zachary Chalmers } \\ 1699 & \text { James Suh } \\ 1711 & \text { Ravindra Kolhe } \\ 1711 & \text { Alka Chaubey } \\ 1711 & \text { Barbara R DuPont } \\ 1712 & \text { Richard Levenson } \\ 1724 & \text { Benjamin R Kipp } \\ 1738 & \text { Ralph H Hruban } \\ 1747 & \text { David T Ting } \\ 1747 & \text { Vikram Deshpande } \\ 1754 & \text { Ralph H Hruban } \\ 1757 & \text { Mari Mino-Kenudson } \\ 1760 & \text { Yutaka Hatanaka }\end{array}$

1772
Ralph H Hruban Randall E Brand

Ralph H Hruban Siraj M Ali Joel Greenbowe Jeffrey S Ross Jo-Anne Vergilio James Suh Siraj M Ali Jeffrey S Ross Vincent A Miller Julia A Elvin Juliann Chmielecki Lee Albacker Philip J Stephens Jason Harris Michael J Clark John West Richard Chen Christian Haudenschild Nan Leng Massimo Morra Shujun Luo Sean M Boyle Deanna M Church Ravi K Alla Martina Lefterova Elena Helman Siraj M Ali Jeffrey S Ross Julia A Elvin

\section{Relevant Disclosure Information}

Consultant for Incyte, Inc.; Salary.

Research support to institution for Affymetrix; Research support to institution.

Speaker, research support for Affymetrix; Research support.

Principle Investigator for Abbott Molecular Inc; Grant support.

Part-time pathologist for Foundation Medicine; Payment for work.

Employee of Foundation Medicine, Inc.; Employment/equity interest.

Employee, research support for Foundation Medicine; Employment, equity.

Employee of Foundation Medicine, Inc.; Employment/equity interest.

Employee of Foundation Medicine, Inc.; Employment/equity interest.

Employee of Foundation Medicine, Inc.; Employment/equity interest.

Part-time pathologist for Foundation Medicine; Payment for work.

Employee of Foundation Medicine, Inc.; Employment/equity interest.

Employee of Foundation Medicine, Inc.; Employment/equity interest.

Employee of Foundation Medicine, Inc.; Employment/equity interest.

Employee of Foundation Medicine, Inc.; Employment/equity interest.

Researcher for Affymetrix Inc.; Kits and Reagents (no direct financial benefit).

Speaker for Affymetrix; Travel benefits. Speaker for Cartagenia; Travel benefits.

Speaker for Abbott; Travel funds.

Founder of MUSE Microscopy, INc; Founder shares. Consultant for Agilent; Payment.

Principle Investigator for Abbott Molecular Inc; Grant support.

PalB2 invention for Myriad Genetics; Royalties.

Research for Affymetrix; Research support.

Research support to institution for Affymetrix; Research support to institution.

PalB2 invention for Myriad Genetics; Royalties.

Consultant for Merrimack Pharmaceuticals; Consultation fee.

Scientific adviser for TAIHO Pharmaceutical Co., Ltd.; Consulting fee. Scientific adviser for GeneticLab Co., Ltd.; Consulting fee. Principal Investigator for QIAGEN K.K. Japan; Collaborative research expense. Principal Investigator for GeneticLab Co., Ltd.; Collaborative research expense.

PalB2 invention for Myriad Genetics; Royalties.

Consultant for Myriad Genetics, Inc.; Honorarium. Scientific advisory board for Asuragnen, Inc.;

Honorarium.

PalB2 invention for Myriad Genetics; Royalties.

Employee of Foundation Medicine, Inc.; Employment/equity interest.

Employee of Foundation Medicine; Employee, equity.

Employee, research support for Foundation Medicine; Employment, equity.

Employee of Foundation Medicine, Inc.; Employment/equity interest.

Employee of Foundation Medicine, Inc.; Employment/equity interest.

Employee of Foundation Medicine, Inc.; Employment/equity interest.

Employee, research support for Foundation Medicine; Employment, equity.

Employee of Foundation Medicine, Inc.; Employment/equity interest.

Employee of Foundation Medicine, Inc.; Employment/equity interest.

Employee of Foundation Medicine, Inc.; Employment/equity interest.

Employee of Foundation Medicine, Inc.; Employment/equity interest.

Employee of Foundation Medicine, Inc.; Employment/equity interest.

Employee of Personalis, Inc; Salary.

Employee of Personalis, Inc; Salary.

Employee of Personalis, Inc; Salary.

Employee of Personalis, Inc; Salary.

Employee of Personalis, Inc; Salary.

Employee of Personalis, Inc; Salary.

Employee of Personalis, Inc; Salary.

Employee of Personalis, Inc; Salary.

Employee of Personalis, Inc; Salary.

Employee of Personalis, Inc; Salary.

Employee of Personalis, Inc; Salary.

Employee of Personalis, Inc; Salary.

Employee of Personalis, Inc; Salary.

Employee of Foundation Medicine, Inc.; Employment/equity interest.

Employee, research support for Foundation Medicine; Employment, equity.

Employee of Foundation Medicine, Inc.; Employment/equity interest. 


$\begin{array}{ll}\text { Abstract } & \text { Name } \\ 1795 & \text { Philip J Stephens } \\ 1795 & \text { Vincent A Miller } \\ 1795 & \text { James Suh } \\ 1795 & \text { Zachary Chalmers } \\ 1795 & \text { Jo-Anne Vergilio } \\ 1795 & \text { Garrett Frampton } \\ 1795 & \text { Laurie Gay } \\ 1796 & \text { Daniel DeSloover } \\ 1796 & \text { Robert Daber } \\ 1797 & \text { Zoran Gatalica } \\ 1797 & \text { Inga Rose } \\ 1797 & \text { Peggy Teresi } \\ 1797 & \text { Rebecca Feldman } \\ 1797 & \text { Ryan P Bender } \\ 1804 & \text { Alka Chaubey } \\ 1804 & \text { Andrew Hadd } \\ 1804 & \text { Ravindra Kolhe } \\ 1805 & \text { Scott A Tomlins }\end{array}$

1813 Wei-Li Liao

$1813 \quad$ Fabiola Cecchi

$1813 \quad$ Adele Blackler

1813 Todd Hembrough

1818

1821

1821

1853

1853

1854
Sydney D Finkelstein

David T Ting

Vikram Deshpande

Julia A Elvin

Siraj M Ali

Peter B Illei

\section{Benjamin R Kipp}

Jeffrey S Ross

Scott Boerner

David M Hwang

Ming-Sound Tsao

Gary M Hunninghake

Lynette M Sholl

Justin F Gainor

Mari Mino-Kenudson

Ryan Hoff

Placede Tiemeny

Susanne Wagner

Xiao-Jun Ma

Yuling Luo

Lynette M Sholl

Marie Christine Aubry

Dennis O’Malley

\section{Relevant Disclosure Information}

Employee of Foundation Medicine, Inc.; Employment/equity interest. Employee of Foundation Medicine, Inc.; Employment/equity interest. Employee of Foundation Medicine, Inc.; Employment/equity interest. Employee of Foundation Medicine, Inc.; Employment/equity interest. Employee of Foundation Medicine, Inc.; Employment/equity interest. Employee of Foundation Medicine, Inc.; Employment/equity interest. Employee of Foundation Medicine, Inc.; Salary/stock options.

Employee of Color Genomics; Salary.

Employee of Bio-Reference Laboratories; Salary.

Employee of Caris Life Sciences; Salary.

Employee of Caris Life Sciences; Salary.

Employee of Caris Life Sciences; Salary.

Employee of Caris Life Sciences; Salary.

Employee of Caris Life Sciences; Salary.

Speaker for Affymetrix; Travel benefits. Speaker for Cartagenia; Travel benefits.

Salaried Employee of Asuragen Inc.; Salary.

Researcher for Affymetrix Inc.; Kits and Reagents (no direct financial benefit).

Consultant for Ventana Medical Systems and Abbvie; Honorarium. Licensced intellectual property for Ventana Medical Systems; Patent royalties. Licensced intellectual property for GenProbe/Hologic; Patent royalties. Sponsored research agreement for Compendia Bioscience/Life Technologies/ThermoFisher Scientififc; Research funding.

Employee of Oncoplex Diagnostics/Nantomics; Salary. Employee of Oncoplex Diagnostics/ Nantomics; Stocks.

Employee of Oncoplex Diagnostics/Nantomics; Salary. Employee of Oncoplex Diagnostics/ Nantomics; Stocks.

Employee of Oncoplex Diagnostics/Nantomics; Salary. Employee of Oncoplex Diagnostics/ Nantomics; Stocks.

Employee of Oncoplex Diagnostics/Nantomics; Salary. Employee of Oncoplex Diagnostics/ Nantomics; Stocks.

Employee of RedPath / Interpace Diagnostics; Salary.

Research for Affymetrix; Research support.

Speaker, research support for Affymetrix; Research support.

Employee of Foundation Medicine, Inc.; Employment/equity interest.

Employee of Foundation Medicine, Inc.; Employment/equity interest.

Scientific advisory board for Genentech; Honorarium. Scientific advisory board for Roche;

Honorarium. Speaker webinar faculty for Roche Diagnostics; Honorarium. Speaker - Workshop

Faculty at WCLC 2015 for AstraZeneca; Honorarium. Scientific advisory board for Myriad

Genetics; Honorarium.

Principle Investigator for Abbott Molecular Inc; Grant support.

Employee, research support for Foundation Medicine; Employment, equity.

Speaker for Pfizer; Honorarium.

Speaker for Pfizer; Honorarium.

Speaker for Pfizer; Honorarium. Consultant for Pfizer; Honorarium. Principal Investigator for

Pfizer; Research grant. Consultant for Novartis; Honorarium.

Consulting for Medna LLC; Honorarium. Consulting for George Lehman Group; Honorarium. Scientific advisory board for "Patients Like Me"; Honorarium. Scientific advisory board for Genentech; Honorarium.

Scientific advisory board for Genentech; Honorarium.

Consultant for Boehringer Ingelheim; Consulting fee. Consultant for Novartis; Consulting

fee. Consultant for Merck; Consulting fee. Consultant for Clovis Oncology; Consulting fee.

Consultant for Jounce Therapeutics; Travel reimbursement. Consultant for Kyowa Hakko Kirin

Pharmaceuticals; Consulting fee.

Consultant for Merrimack Pharmaceuticals; Consultation fee.

Employee of Myriad Genetics, Inc., Salt Lake City, UT; Receives salary and stock options.

Employee of Myriad Genetics, Inc., Salt Lake City, UT; Receives salary and stock options.

Employee of Myriad Genetics, Inc., Salt Lake City, UT; Receives salary and stock options.

Employee of Advanced Cell Diagnostics; Employee.

Employee of Advanced Cell Diagnostics; Stock.

Scientific advisory board for Genentech; Honorarium.

Consultant for Genentech; Honorarium.

Employee of Clarient Pathology Services; Salary. 


$\begin{array}{ll}\text { Abstract } & \text { Name } \\ 1900 & \text { Bruce E Johnson } \\ 1900 & \text { Lynette M Sholl } \\ 1909 & \text { Lynette M Sholl } \\ 1909 & \text { Pasi A Janne }\end{array}$

1911

1911

1918

1919

1920

1922

1922

1922

1927

1927

1927

1927

1927

1927

1927

1927

1927

1927

1927

1932

2026

2026

2026

2026

2026

2026

2026

2026

2031

2031

2031

2031

2039

2039

2039

2048

2048

2048

2048

2048

2048
Marie Christine Aubry Geoffrey B Johnson Hans-Ulrich Schildhaus

Diana N Ionescu Mari Mino-Kenudson Lynette M Sholl Cloud Paweletz Geoffrey R Oxnard Jo-Anne Vergilio Julia A Elvin Jeffrey S Ross Philip J Stephens Vincent A Miller James Suh Juliann Chmielecki Garrett Frampton

Kai Wang

Siraj M Ali Adrienne Johnson Lynette M Sholl Bingqing Zhang Xiao-Jun Ma Yuling Luo Henry G Lamparski $\mathrm{Nan} \mathrm{Su}$ Melanie Miller Casey Kernag Thomas Laver Claire Attwooll Lisa C Watson Ravindra Kolhe Alka Chaubey Clifford C Hoyt Alejandro Contreras Chichung Wang Sangheum Hwang

Hyo-Eun Kim

Sangyong Song

Sooyoun Cho

Soohyun Hwang

Jungin Lee

Hyemin Shim

Yuling Luo

Keith Young

\section{Relevant Disclosure Information}

Consulting for KEW Group-Genomic Testing Company; Honoraria.

Scientific advisory board for Genentech; Honorarium.

Scientific advisory board for Genentech; Honorarium.

Consultant, commercial research support for AstraZeneca; Consulting fee, research support.

Consultant for Pfizer; Consulting fee. Consultant for Roche; Consulting fee. Consultant for Acea

Biosciences; Consulting fee. Consultant for Chugai Pharmaceuticals; Consulting fee. Commercial research support for Astellas; Research support. Stock ownership for Gatekeeper pharmaceuticals; Owns stock. On DFCI-owned intellectual property on EGFR mutations licensed to Lab Corp for

Lab Corp; Post-marketing royalties.

Consultant for Genentech; Honorarium.

Advisory panel for Pfizer Inc.; Honorarium.

Speaker for Abbott Molecular; Honorarium. Speaker for ZytoVision; Honorarium. Speaker for

Pfizer; Honorarium.

Speaker at CME events for Pfizer; Honorarium.

Consultant for Merrimack Pharmaceuticals; Consultation fee.

Scientific advisory board for Genentech; Honorarium.

Speaker for BioRad; Honorarium.

Consultant for Sysmex; Honorarium.

Employee of Foundation Medicine, Inc.; Employment/equity interest.

Employee of Foundation Medicine, Inc.; Employment/equity interest.

Employee, research support for Foundation Medicine; Employment, equity.

Employee of Foundation Medicine, Inc.; Employment/equity interest.

Employee of Foundation Medicine, Inc.; Employment/equity interest.

Employee of Foundation Medicine, Inc.; Employment/equity interest.

Employee of Foundation Medicine, Inc.; Employment/equity interest.

Employee of Foundation Medicine, Inc.; Employment/equity interest.

Employee of Foundation Medicine, Inc.; Employment/equity interest.

Employee of Foundation Medicine, Inc.; Employment/equity interest.

Employee of Foundation Medicine, Inc.; Employment/stock ownership.

Scientific advisory board for Genentech; Honorarium.

Employee of Advanced Cell Diagnostics; Salary, stock.

Employee of Advanced Cell Diagnostics; Employee.

Employee of Advanced Cell Diagnostics; Stock.

Employee of Advanced Cell Diagnostics; Salary, stock.

Employee of Advanced Cell Diagnostics; Salary, stock.

Employee of Advanced Cell Diagnostics; Salary, stock.

Employee of Advanced Cell Diagnostics; Salary, stock.

Employee of Advanced Cell Diagnostics; Salary, stock.

Salaried Employee of Illumina, Inc; Salary.

Company Employee of Illumina, Inc; Salary and stocks.

Researcher for Affymetrix Inc.; Kits and Reagents (no direct financial benefit).

Speaker for Affymetrix; Travel benefits. Speaker for Cartagenia; Travel benefits.

Employee of PerkinElmer; Salary.

Speaker for PerkinElmer; Travel expenses.

Employee of PerkinElmer; Salary.

Researcher for Ministry of Science, ICT and Future Planning, Government of Republic of Korea; Research grant.

Researcher for Ministry of Science, ICT and Future Planning, Government of Republic of Korea; Research grant.

Researcher for Ministry of Science, ICT and Future Planning, Government of Republic of Korea; Research grant.

Researcher for Ministry of Science, ICT and Future Planning, Government of Republic of Korea; Research grant.

Researcher for Ministry of Science, ICT and Future Planning, Government of Republic of Korea; Research grant.

Researcher for Ministry of Science, ICT and Future Planning, Government of Republic of Korea; Research grant.

Researcher for Ministry of Science, ICT and Future Planning, Government of Republic of Korea; Research grant.

Employee of Advanced Cell Diagnostics; Stock.

Employee of Advanced Cell Diagnostics; Salary, stock. 


\begin{tabular}{|c|c|}
\hline Abstract & Name \\
\hline 2051 & Xiao-Jun Ma \\
\hline 2051 & $\mathrm{Nan} \mathrm{Su}$ \\
\hline 2051 & Kuang-Jung Chang \\
\hline 2051 & Casey Kernag \\
\hline 2051 & Thomas Laver \\
\hline 2051 & Melanie Miller \\
\hline 2051 & Henry G Lamparski \\
\hline 2051 & Daniel Kim \\
\hline 2051 & Bingqing Zhang \\
\hline 2052 & Mirian Karbelashvili \\
\hline 2052 & Richard Chen \\
\hline 2052 & John West \\
\hline 2052 & Deanna M Church \\
\hline 2052 & Parin Sripakdeevong \\
\hline 2052 & Scott Kirk \\
\hline 2052 & Elena Helman \\
\hline 2052 & Martina Lefterova \\
\hline 2052 & Massimo Morra \\
\hline 2052 & Shujun Luo \\
\hline 2052 & Ravi K Alla \\
\hline 2052 & Michael J Clark \\
\hline 2052 & Sean M Boyle \\
\hline 2052 & Michael P Snyder \\
\hline 2053 & Richard Levenson \\
\hline 2054 & Yonghua Zhang \\
\hline 2054 & Zhiqing Zhang \\
\hline 2056 & James Mansfield \\
\hline 2057 & James Mansfield \\
\hline 2057 & Kristin Roman \\
\hline 2057 & Chichung Wang \\
\hline 2057 & Clifford C Hoyt \\
\hline 2062 & Ahmet Dogan \\
\hline 2067 & Hartmut Koeppen \\
\hline 2067 & Chenery Lowe \\
\hline 2067 & Sandra Rost \\
\hline 2076 & Sydney D Finkelstein \\
\hline 2078 & Claude Sirlin \\
\hline 2082 & Ulrich Vogel \\
\hline 2084 & Yonghua Zhang \\
\hline 2084 & Zhiqing Zhang \\
\hline 2085 & Casey Kernag \\
\hline 2085 & Xiao-Jun Ma \\
\hline 2085 & $\mathrm{Nan} \mathrm{Su}$ \\
\hline 2085 & Daniel Kim \\
\hline 2085 & Yuling Luo \\
\hline 2085 & Bingqing Zhang \\
\hline 2085 & Henry G Lamparski \\
\hline 2089 & Luis Chavez \\
\hline 2089 & Erico von Bueren \\
\hline 2089 & Julie A Galindo \\
\hline 2089 & Carlos Sanchez \\
\hline 2089 & Cliff Hom \\
\hline 2089 & Douglas T Yamanishi \\
\hline 2089 & Lydia E Figueroa \\
\hline 2090 & Eugenie Dalimier \\
\hline 2090 & Anil Parwani \\
\hline
\end{tabular}

\section{Relevant Disclosure Information}

Employee of Advanced Cell Diagnostics; Employee. Employee of Advanced Cell Diagnostics; Salary, stock. Employee of Advanced Cell Diagnostics; Salary, stock. Employee of Advanced Cell Diagnostics; Salary, stock. Employee of Advanced Cell Diagnostics; Salary, stock. Employee of Advanced Cell Diagnostics; Salary, stock. Employee of Advanced Cell Diagnostics; Salary, stock. Employee of Advanced Cell Diagnostics; Salary, stock. Employee of Advanced Cell Diagnostics; Salary, stock. Employee of Personalis, Inc; Salary. Employee of Personalis, Inc; Salary. Employee of Personalis, Inc; Salary. Employee of Personalis, Inc; Salary. Employee of Personalis, Inc; Salary. Employee of Personalis, Inc; Salary. Employee of Personalis, Inc; Salary. Employee of Personalis, Inc; Salary. Employee of Personalis, Inc; Salary. Employee of Personalis, Inc; Salary. Employee of Personalis, Inc; Salary. Employee of Personalis, Inc; Salary. Employee of Personalis, Inc; Salary.

Membership on advisory committee for Personalis, Inc; Stock.

Founder of MUSE Microscopy, INc; Founder shares. Consultant for Agilent; Payment.

Employee of NovoDiax, Inc.; Employee.

Employee of NovoDiax, Inc.; Employee.

Employee of PerkinElmer; Salary.

Employee of PerkinElmer; Salary.

Employee of PerkinElmer; Salary.

Employee of PerkinElmer; Salary.

Employee of PerkinElmer; Salary.

Consultant for Foundation Medicine; Stipend. Advisory board for Cancer Genetics; Stipend.

Full time Employee of Roche; Salary, options, shares.

Contractor for Roche; Salary.

Full time Employee of Roche; Salary, options, shares.

Employee of RedPath / Interpace Diagnostics; Salary.

Research contract for General Electric Healthcare; None. Research contract for Siemens; None. Inventor of Patent application by myself. No company.; Nothing. A patent application only costs. Employee of NovoDiax, Inc.; Employee.

Employee of NovoDiax, Inc.; Employee.

Employee of Advanced Cell Diagnostics; Salary, stock.

Employee of Advanced Cell Diagnostics; Employee.

Employee of Advanced Cell Diagnostics; Salary, stock.

Employee of Advanced Cell Diagnostics; Salary, stock.

Employee of Advanced Cell Diagnostics; Stock.

Employee of Advanced Cell Diagnostics; Salary, stock.

Employee of Advanced Cell Diagnostics; Salary, stock.

Employee of Sakura Finetek USA, Inc.; Salary.

Employee of Sakura Finetek USA, Inc.; Salary.

Employee of Sakura Finetek USA, Inc.; Salary.

Employee of Sakura Finetek USA, Inc.; Salary.

Employee of Sakura Finetek USA, Inc.; Salary.

Employee of Sakura Finetek USA, Inc.; Salary.

Employee of Sakura Finetek USA, Inc.; Salary.

Employee of LLTech; Salary.

Dr. Parwani also formerly served as a consultant to Omnyx, LLC, through an agreement with the University of Pittsburgh Department of Pathology for Omnyx, LLC; Dr. Parwani was formerly employed by an affiliate of UPMC, which owns one half of Omnyx, LLC. He received research funding from Omnyx, LLC through the Univ. of Pitt, and has the right to receive proceeds from the sale of Omnyx or its products.

Employee of LLTech; Salary. 


\section{XUSCAP}

Abstract Name

$2091 \quad$ Jillian Tyrrell

2091 David Tacha
Relevant Disclosure Information

Employee of Biocare Medical; Salary.

Employee of Biocare Medical; Stock. 